\title{
Prevalence of chronic
} obstructive pulmonary disease in Zonguldak province of Turkey

\author{
Tacettin ÖRNEK ${ }^{1}$ \\ Meltem TOR ${ }^{1}$ \\ Sibel KIRAN ${ }^{2}$ \\ Figen ATALAY ${ }^{1}$
}

${ }^{1}$ Department of Chest Diseases, Faculty of Medicine, Bulent Ecevit University, Zonguldak, Turkey

${ }^{1}$ Bülent Ecevit Üniversitesi Tıp Fakültesi, Göğ̈̈s Hastalıkları Anabilim Dalı, Zonguldak, Türkiye

2 Department of Public Health, Faculty of Medicine, Hacettepe University, Ankara, Turkey

${ }^{2}$ Hacettepe Üniversitesi Tıp Fakültesi, Halk Sağlığı Anabilim Dalı, Ankara, Türkiye

\section{SUMMARY}

Prevalence of chronic obstructive pulmonary disease in Zonguldak province of Turkey

Introduction: Chronic Obstructive Pulmonary Disease (COPD) is increasingly recognized as a leading cause of global morbidity and mortality. This study is the first spirometry-based, cross-sectional survey of COPD from Western Black Sea Region of Turkey. In this study we aimed to investigate COPD prevalence in Zonguldak province of Turkey.

Materials and Methods: Adult population of 71.630 persons living in central Zonguldak were enrolled to the study. They were selected by random sampling methods based on regional inhabitant listings. 611 adult persons were finally enrolled to the study. They were interviewed face to face, and were given a questionnaire. Spirometry and early reversibility testing were also performed. Results were evaluated according to Global Obstrucive Lung Disease (GOLD) criteria.

Results: $42.6 \%$ of the study population were males. Mean age was $49.2 \pm 15.4$. The number of inividuals 40 years and older was $447(73.1 \%)$. COPD prevalence was found as $11.1 \%$ in the study population and $14.1 \%$ in the population 40 years and older. COPD prevalence in males and females 40 years and older were $19.6 \%$ and $9.8 \%$ respectively. Mean age of the COPD patients $(60.06 \pm 13.2$ years) was higher than the subjects without COPD $(47.8 \pm 15.1)(p<0.001)$. COPD prevalence was increasing with age categories. COPD severity based on GOLD criteria were as follows: Stage 1 (23.5\%), Stage 2 (58.8\%), Stage 3 (16.2\%) and Stage $4(1.5 \%)$. Prevalence of smoking history was $95.3 \%$ in male COPD patients, and $56 \%$ in female COPD patients. Smoking was the most common risk factor present in $80.9 \%$ of COPD cases, followed by biomass exposure (63.2\%), occupational exposure $(41.2 \%)$ and passive smoking (7.3\%). Smoking history and occupational exposure were higher statistically in males than females in both study populatian and COPD cases.

Conclusion: COPD is prevalent and an important public health problem in central Zonguldak province.

Key words: Epidemiology, smoking, spirometry

\section{ÖZET}

Zonguldak il merkezinde kronik obstrüktif akciğer hastalı̆̆ı prevalansı

Giriş: Günümüzde Kronik Obstrüktif Akciğer Hastalı̆̆ı (KOAH), tüm dünya ülkelerinde önemli bir sağlık sorunu haline gelmiştir. Diğer hastalıkların mortalite oranlarının yıllar içinde düşmesine karşılık KOAH prevalansı ve mortalitesi giderek artış göstermekte-

\section{Yazışma Adresi (Address for Correspondence)}

Dr. Tacettin ÖRNEK

Bülent Ecevit Üniversitesi Tıp Fakültesi, Göğüs Hastalıkları Anabilim Dalı, Kozlu, ZONGULDAK - TURKEY

e-mail: tacettinornek@yahoo.com 
dir. Bu çalışma Batı Karadeniz Bölgesinde yapılan ilk spirometrik ve kesitsel KOAH prevelans çalışmasıdır. Bu araştırmada Zonguldak il merkezinde KOAH prevelansını belirlemek amaçlanmıştır.

Materyal ve Metod: Zonguldak il merkezinde yaşayan 18 yaş ve üzeri 71.630 kişi çalışmanın hedef popülasyonu olarak kabul edildi. Hedef popülasyondan 611 kişiye, mahalle ve sokak temelinde küme ve sistematik örnekleme yöntemleri birlikte kullanılarak ulaşıldı. Araştırmaya katılan bireylere yüz yüze görüşme yöntemiyle anket formu dolduruldu ve solunum fonksiyon testi ile birlikte erken reversibilite testi yapıldı. Sonuçlar Global Obstrucive Lung Disease (GOLD) kriterlerine göre değerlendirildi.

Bulgular: Çalışmaya katılan bireylerin \%42.6'sı erkek idi. Yaş ortalaması $49.20 \pm 15.4$ bulundu. Kırk yaş ve üstü birey sayısı 447 (\% 73.1 ) idi. KOAH prevalansı çalışma grubunda \% 11.1, 40 yaş ve üstü bireylerde ise \% 14.1 olarak saptandı. Kırk yaş ve üstü erkeklerde KOAH prevelansı \% 19.3, kadınlarda ise \%9.8 idi. KOAH saptanan hastaların yaş ortalaması (60.06 \pm 13.2$)$ KOAH saptanmayan bireylerin yaş ortalamasından $(47.8 \pm 15.1)$ fazlaydı $(p<0.001)$. Yaş kategorileri arttıkça KOAH prevelansının da arttığı tespit edildi. GOLD spirometrik sınıflandırmasına göre KOAH'lı hastaların \%23.5'i Evre 1'de, \%58.8'i Evre 2'de \% 16.2'si Evre 3'de ve \% 1.5'i Evre 4'te tespit edildi. Sigara içme öyküsü erkek KOAH'lı hastaların \%95.3'ünde, kadın KOAH'lı hastaların ise \%56'sında mevcut idi. KOAH'ı hastalarda en sık görülen risk faktörleri sırasıly sigara (\%80.9), biomass maruziyeti (\%63.2), mesleksel maruziyet (\%41.2) ve pasif sigara içiciliği idi. Sigara ve mesleksel maruziyet hem çalışma grubunda hem de KOAH'lı hastalarda erkeklerde daha sık görülmekteydi.

Sonuç: KOAH Zonguldak il merkezinde çok belirgindir ve önemli bir halk sağlığı sorunudur.

Anahtar kelimeler: Epidemiyoloji, sigara, spirometri

\section{INTRODUCTION}

Chronic Obstructive Lung Disease (COPD) is a disease of increasing prevalence, morbidity and mortality, but suffers from underrecognition, underdiagnosis and undertreatment. It has been defined by the Global Initiative for Chronic Obstructive Lung Disease (GOLD) as a "preventable and treatable disease with some significant extrapulmonary effects that may contribute to the severity in individual patients. Its pulmonary component is characterized by airflow limitation that is not fully reversible. The airflow limitation is usually progressive and associated with an abnormal inflammatory response of the lung to noxious particles or gases" (1).

Actual prevalence of COPD worldwide is unknown because of variation due to differences in survey methods (doctor diagnosed, spirometry based, symptom based etc), diagnostic criteria and analytic approaches. Worldwide, cigarette smoking is the most commonly encountered risk factor for COPD. Air pollution resulting from the burning of wood and other biomass fuels, and occupational exposure to noxious gases and particles have also been identified as other COPD risk factors $(2,3)$. Diagnosed prevalence and morbidity data underestimate the total burden of COPD because the disease is usually not diagnosed until it is clinically apparent, and there is considerable variation in reported prevalence (4). Lowest prevalence is generally reported from studies based on doctor diagnosis, and higher prevalence is reported from symptom-based surveys. Spirometry based studies report prevalence rates in between and is now accepted as the gold standard method in epidemiologic studies for COPD. Latin American Project for the Investigation of Obstructive Lung Disease (PLATINO) study from
South America and Burden of Obstructive Lung Disease (BOLD) Study used the fixed ratio $\left(\mathrm{FEV}_{1} / \mathrm{FVC}<\right.$ $0.7)$ as a measure of obstruction and reported a prevalence of around 20\% (5).

Mortality data also underestimate COPD as a common cause of death, but again COPD is now the fourth leading cause of death and will become the third leading cause of death by $2020(6,7)$.

Despite the increasing trend in the COPD prevalence, there are limited data from Turkey. In this study, we aimed to measure the prevalence of spirometrically confirmed COPD in a population of adults aged 18 years or more with at least one risk factor, and to evaluate the characteristics and risk factors of the COPD patients.

\section{MATERIALS and METHODS}

\section{Subjects and Protocol}

This study was performed between September and October 2005 in central township of Zonguldak province of Turkey, which has a population of 71,630 adults aged 18 years or more according to National Institute of Statistics of Turkey (TUIK) at the time of the study. The study protocol was approved by the local Ethics Committee. Informed consent was obtained from all subjects. The smallest number $(n=382)$ which represented this population according to $95 \%$ confidence interval with a $20 \%$ prevalence \pm 5 deviation was calculated by Epi Info/Statcalc software. This number was assumed as the number of households that should be reached. Central town of Zonguldak province is consisted of 19 districts. Three hundred and eighty-two households were randomly selected from regional inhabitant lists of these 
districts. Neighbouring house was used as refill. Total of 611 subjects from 382 households completed the study. All participants were interviewed face to face, and a questionnaire which was modified from BOLD questionnaire was given. The questionnaire included demographic characteristics of the patients, body mass index (BMI), smoking habit, questions related to the presence of symptoms and indoor or outdoor exposure to irritant gases or fumes. Persons who were unable to answer the questionnaire and/or unable to perform spirometric test were excluded.

\section{Spirometric Examination}

Standard spirometric examination was performed on all subjects. All spirometric examinations were carried out using the same portable spirometer (Spirolab II, Medical International Research) and in a sitting position. Accordingly, an effort was made to obtain three technically acceptable spirograms and the highest value was recorded. Early reversibility testing was performed for the patients who had Forced Expiratory Volume in first second/ Forced Vital Capacity (FEV $/$ FVC) values less than 0.7. Those subjects inhaled 200 $\mu \mathrm{g}$ salbutamol (Ventolin inhaler, GSK), and spirometric examination was repeated 15 minutes later to test for reversibility. An increase in $\mathrm{FVC}$ and/or $\mathrm{FEV}_{1}$ greater than $12 \%$ of the baseline and greater than $200 \mathrm{~mL}$ constituted a positive early reversibility test. In active smokers, spirometric examination was delayed at least one hour after cigarette smoking. In subjects using long acting beta-2 agonist, oral beta- 2 agonist, long acting anticholinergic or oral theophylline, spirometric examination was postponed at least one day, and in those taking short acting beta-2 agonists or short acting anticholinergic test was postponed at least 4 hours.

\section{Definitions}

Persons with at least one risk factor (smoking history, passive smoking, biomass exposure, occupational exposure at least one year), and a post-bronchodilator $\mathrm{FEV}_{1} / \mathrm{FVC}$ values less than 0.7 and negative reversibility were defined as COPD patients. COPD severity was classified according to 2007 GOLD report (1).

Persons smoking currently with more than 20 packs of cigarettes through entire life or more than one cigarette throughout at least one year were defined as current smokers. Persons who gave up smoking more than one month ago were defined as exsmokers. If a subject had a smoking history, this means the subject was either a current smoker or exsmoker. Nonsmokers who were living with a smoker at the same room and were exposed to cigarette smoke were considered passive smokers.

Occupational exposure was defined as working at least one year in occupations with dusts, fumes or chemical gases.

Biomass exposure was defined as using plants or plants-derived materials (wood, coal, etc.) indoor and outdoor for heating or cooking.

\section{Statistical Analysis}

Data analysis was conducted using SPSS v. release 11.01 statistical software (SPSS Inc, Chicago, Illionis, US, April 2002, Customer number: 114094). Continuous variables were summarised as means $( \pm$ $\mathrm{SD}$ ). For independent samples, $\mathrm{t}$ test were used to analyse the group difference between quantitative variables as appropriate. Fisher's exact test or Chisquare test were used to analyse the distribution of categorical variables. $\mathrm{p}<0.05$ was considered as statistically significant. The results of the analysis were assessed with 95\% confidence interval.

\section{RESULTS}

Six hundred and eleven subjects from 382 households completed the study. Two hundred and sixty $(42.6 \%)$ of the study population were males. Mean age of the study population was $49.20 \pm 15.4$ years (age range 18-87). Four hundred and forty-seven ( $73.1 \%$ ) were above 40 years of age. Coal mining was the most common occupation seen in $14.9 \%$ of cases (91/611).

COPD prevalence in the study population above 18 years of age and in the subjects above 40 years of age was found as $11.1 \%(16.5 \%$ in males and $7.1 \%$ in females) and $14.1 \%(19.3 \%$ in males and $9.8 \%$ in females) respectively (Table 1). Mean age of the COPD patients (60.06 \pm 13.2 years) was higher than the subjects without COPD $(47.8 \pm 15.1)(p<0.001)$. Of 68 COPD patients, only five $(7.3 \%)$ were under 40 years of age (four males and one female). All of them were smokers, and two of them were coal miners.

Smoking in pack years was significantly higher in COPD group compared to non-COPD group, while BMI did not differ significantly between COPD and non-COPD group (Table 2). COPD prevalence was increasing significantly with age categories $(p=$ 0.036), Odds Ratio (OR) reaching to 1.51 for the subjects above 70 years of age (Table 3 ).

Risk factors in the study population and COPD subjects were shown in Table 4 and Table 5 respectively. Of 611 subjects, $553(90.5 \%)$ had at least one risk factor for 
COPD. In COPD cases, while most COPD patients had multiple risk factors, $19.1 \%$ reported only smoking, $11.8 \%$ only biomass exposure and $4.4 \%$ only passive smoking as the potential risk factor. None of the COPD patients had occupational exposure as a single risk factor. In the study population, biomass exposure was the most common risk factor followed by smoking (53\%), occupational exposure $(27.3 \%)$ and passive smoking $(19.4 \%)$ (Table 4). In the COPD group, smoking was the most common risk (80.9\%) followed by biomass exposure $(63.2 \%)$, occupational exposure $(41.2 \%)$ and passive smoking (7.3\%) (Table 5).

But risk factors differed with respect to gender. In the study population, biomass exposure $(60.7 \%)$ was the leading risk factor for females followed by smoking $(31.9 \%)$ and passive smoking $(26.5 \%)$, whereas for males smoking $(81.5 \%)$ was the leading risk factor followed by biomass (65\%) and occupational exposure $(56.9 \%)$ (Table 4$)$. In the COPD group, biomass exposure $(60 \%)$ was the leading risk factor for females followed by smoking (56\%) and passive smoking (16\%) whereas for males, smoking $(95.3 \%)$ was the leading risk factor followed by biomass $(65.1 \%)$ and occupational exposures (65.1\%). Smoking history and occupational exposure were statistically more common in males than in females in both study populatian and COPD group as expected and passive smoking was statistically more common in females than in males in both groups. Biomass exposure was equally potent risk factor for both males and females (Tables 4 and 5).

While current smoking prevalence was 34\% (51.5\% in males, $21 \%$ in females), in the study population, $53 \%(81.5 \%$ of males, $31.9 \%$ of females $)$ had a

Table 1. COPD prevalence according to gender

\begin{tabular}{|lccc|}
\hline Age & Male & Female & Overall \\
\hline$\geq 40$ years - no./total no. (\%) & $39 / 202(19.3)$ & $24 / 245(9.8)$ & $63 / 447(14.1)$ \\
$\geq 18$ years - no./total no. $(\%)$ & $43 / 260(16.5)$ & $25 / 351(7.1)$ & $68 / 611(11.1)$ \\
\hline & & & \\
\hline
\end{tabular}

Table 2. Comparative data between the subjects with COPD and without COPD

\begin{tabular}{|lccc|}
\hline Data & COPD $(\mathbf{n}=\mathbf{6 8})$ & Non - COPD $(\mathbf{n}=\mathbf{5 4 3})$ & $\mathbf{p}^{*}$ \\
\hline Smoking (pack-years) (mean \pm SD) & $41.7 \pm 24.7$ & $26.2 \pm 24.8$ & $<0.001$ \\
Body moss index (mean \pm SD) & $25.4 \pm 4.1$ & $26.4 \pm 4.5$ & 0.085 \\
Age (mean \pm SD) & $60.1 \pm 13.2$ & $47.8 \pm 15.1$ & $<0.001$ \\
\hline *Independent samples t test was performed. & & & \\
SD: Standard deviation. & & & \\
\hline
\end{tabular}

Table 3. COPD prevalence in age groups

\begin{tabular}{|c|c|c|c|}
\hline Age & No./Total no. & Prevalence (\%) & OR \\
\hline$\geq 18$ years & $98 / 611$ & 11.1 & 1.00 \\
\hline$\geq 40$ years & $63 / 447$ & 14.1 & 0.88 \\
\hline$\geq 50$ years & $52 / 276$ & 18.8 & 1.17 \\
\hline$\geq 60$ years & $39 / 176$ & 22.2 & 1.38 \\
\hline$\geq 70$ years & $17 / 70$ & 24.3 & 1.51 \\
\hline
\end{tabular}

Table 4. Risk factors in study population

\begin{tabular}{|c|c|c|c|c|}
\hline Risk factor & Males & Females & Total & $\mathbf{p}^{*}$ \\
\hline Smoking history - no./total no. (\%) & $212 / 260(81.5)$ & $112 / 351(31.9)$ & $324 / 611(53)$ & $<0.001$ \\
\hline Occupational exposure - no./total no. (\%) & $148 / 260(56.9)$ & $19 / 351(5.4)$ & $167 / 611(27.3)$ & $<0.001$ \\
\hline Passive smoking - no./total no. (\%) & $26 / 260(10.0)$ & $93 / 351(26.5)$ & $119 / 611(19.4)$ & $<0.001$ \\
\hline Biomass exposure - no./total no. (\%) & $169 / 260(65)$ & 213/351 (60.7) & $382 / 611(62.5)$ & 0.311 \\
\hline
\end{tabular}




Table 5. Risk factors in COPD cases
\begin{tabular}{|lcccc|}
\hline Risk factor & Males & Females & Total & p \\
\hline Smoking history - no./total no. $(\%)$ & $41 / 43(95.3)$ & $14 / 25(56.0)$ & $55 / 68(80.9)$ & $<0.001^{*}$ \\
Occupational exposure - no./total no. $(\%)$ & $28 / 43(65.1)$ & $0 / 25(0)$ & $28 / 68(41.2)$ & $<0.001^{*}$ \\
Passive smoking - no./total no. $(\%)$ & $1 / 43(2.3)$ & $4 / 25(16.0)$ & $5 / 68(7.3)$ & $<0.001^{*}$ \\
Biomass exposure - no./total no. $(\%)$ & $28 / 43(65.1)$ & $15 / 25(60.0)$ & $43 / 68(63.2)$ & $0.795^{\ddagger}$ \\
\hline *Fisher's exact test and ${ }^{\ddagger}$ Chi-square test was performed. & & & \\
\end{tabular}

Table 6. COPD stage distribution in different age groups

\begin{tabular}{|lcc|}
\hline Stage & Age $\geq \mathbf{1 8}$ years & Age $\geq \mathbf{4 0}$ years \\
\hline Mild COPD - no./total no. $(\%)$ & $16 / 68(23.5)$ & $15 / 63(23.8)$ \\
Moderate COPD - no./total no. $(\%)$ & $40 / 68(58.8)$ & $36 / 63(57.1)$ \\
Severe COPD - no./total no. $(\%)$ & $11 / 68(16.2)$ & $11 / 63(17.5)$ \\
Very Severe COPD - no./total no. (\%) & $1 / 68(1.5)$ & $1 / 63(1.6)$ \\
\hline *Fisher's exact test and ${ }^{\ddagger}$ Chi-square test was performed. & & \\
\hline
\end{tabular}

smoking history. Passive smoking was more prevalent in females compared to males (26.5\% vs $10 \%)$. Prevalence of smoking was significantly higher in the group with occupational exposure than in the nonexposed group: $81.4 \%(136 / 167)$ vs $42.3 \%$ $(188 / 444) \quad(p<0.001)$. Smoking prevalence among coal miners in the study population was $88.8 \%$ (79/91). $64.3 \%(18 / 28)$ of COPD patients with occupational exposure were coal miners all of whom had a smoking history. COPD prevalence among males with a smoking history, among the occupationally exposed group and among the coal miner group were $19.4 \%(41 / 212), 16.8 \%$ (28/167) and 19.8\% (18/91) respectively.

COPD patients above 18 years of age were classified as follows according to GOLD criteria: Stage 1 $(23.5 \%)$, Stage $2(58.8 \%)$, Stage $3(16.2 \%)$ and Stage 4 $(1.5 \%)$, and above 40 years of age as Stage $1(23.8 \%)$, Stage $2(57.1 \%)$, Stage $3(17.5 \%)$ and Stage $4(1.6 \%)$ (Table 6). GOLD Stage distribution of COPD patients were similar and GOLD Stage 2 was the most common stage in both age groups.

\section{DISCUSSION}

In this study we investigated the prevalence of spirometrically-defined COPD in Zonguldak province of Turkey. We have shown that COPD prevalence in central Zonguldak was $11.1 \%$ and \%14.1 among populations above 18 and 40 years of age respectively. COPD prevalence was significantly higher in males compared to females in both age groups $(16.5 \%$ in males and $7.1 \%$ in females above 18 years of age; $19.3 \%$ in males and $9.8 \%$ in females above 40 years of age). Smoking history was present in $80.9 \%$ of
COPD patients $(95.3 \%$ in the males and $56 \%$ in the females). Smoking history and occupational exposure were statistically more common in males than in females in both study populatian and COPD patients, and passive smoking was statistically more common in females than in males in both groups. Biomass exposure was equally potent risk factor for both males and females.

Halbert et al. reported that overall COPD prevalence rates ranged from $0.2 \%$ to $18 \%$ in 32 studies published between 1962 and 2001 and tended to vary by the method (based on spirometry, respiratory symptoms, patient-reported disease, or expert opinion) used to estimate prevalence (8). Moreover, only 11 studies used spirometry, either in conjunction with a clinical examination or used alone, to reach a prevalence estimate. COPD prevalence rates based on spirometry ranged from $3.7 \%$ to $11 \%$. Lowest prevalence rates $(0.2$ to $2.5 \%)$ were based on expert opinion.

There are still many problems regarding the evaluation of COPD prevalence worldwide. Existing COPD prevalence data show significant variations due to differences in survey methods, diagnostic criteria and analytical approaches (9). In a study from Sweden, COPD prevalence was calculated according to COPD criteria of British Thoracic Society (BTS), European Respiratory Society (ERS), GOLD, American Thoracic Society (ATS) and clinically defined COPD (doctor's diagnosis and symptoms) and were found $7.6 \%, 14.0 \%, 14.1 \%, 34.1 \%$ and $12.2 \%$ respectively (10). These results showed that diagnostic criteria had a considerable impact on COPD prevalence. Many additional sources of variations can influence the 
estimates of COPD prevalence, including sampling methods, spirometric procedures, and whether spirometry was performed pre- or post-bronchodilator. This condition entailed difficulties to compare prevalence values and to watch progression of COPD prevalence. In our study, we preferred to perform random sampling onto cluster sampling based on quarter and street to minimize sampling bias.

Despite all of these difficulties about COPD prevalence calculations, emerging data support the increasing COPD prevalence. The most important data related to COPD prevalence were brought to light with the release of the results of a nationally representative study from the U.S. the NHANES III (Third National Health and Nutrition Survey) (11). Results of this study yielded adult COPD prevalence estimates of 23.6 million population $(13.9 \%$ of the adult population), with approximately $10 \%$ of them being in severe or very severe stages of the disease. The 2005 Latin American Project for the Investigation of Obstructive Lung Disease (PLATINO) study also reported prevalence rates ranging between $8-20 \%$ in five Latin American cities (5). In all cities, the prevalence was appreciably higher in men than women, and higher with increasing age. In a crosssectional survey based on spirometry including 20.245 participitants from China presented $8.2 \%$ prevalence of COPD (12).

There are emerging data from Turkey a well. From rural part of Kayseri province, Turkey, Kiraz, et al. reported chronic bronchitis prevalence in women above 25 years of age in a ECRHS questionnaire based study as $20.7 \%$ (13). In a spirometric study among individuals above 40 years age from Adana, Turkey, which was the BOLD pilot city from Turkey, COPD prevalence was reported as $19.1 \%$ and $14.3 \%$ according to "fixed ratio" and "lower limit of normal" respectively (14). In this study, Kocabas et al. reported the prevalence as $28 \%$ in males and $10.3 \%$ in females according to $\mathrm{FEV}_{1} / \mathrm{FVC}<0.7$. This is the highest ever reported COPD prevalence rate reported from Turkey. In another epidemiological study from Turkey enrolling 1160 participants over 18 years age prevalence of COPD was reported as $6.9 \%$, wherein spirometric values and symptoms were used to define COPD (15). In this study, majority of COPD cases were in GOLD stage 2 similar to the results of our study. In another study from Turkey, Deveci et al. found $4.5 \%$ prevalence of COPD among 1188 individuals over 18 years in Elazig, Eastern Turkey (16). In their study, COPD was defined as airflow obstruction. They didn't combine any other parameters such as symptoms, risk factors to diagnose COPD. Our results were higher than these two major COPD data from Turkey, but lower than the BOLD Adana study. Different definitions and special condition of Zonguldak region about risk factors such as air pollution due to immense coal burning (biomass exposure) and occupational exposure (mostly coal mine dust) explain the differences between reports from the different regions of Turkey.

Smoking, outdoor air pollution, occupational exposure and biomass smoke exposure are the most common risk factors for COPD (17-19). Cigarette smoking is the most important causal factor for developing COPD (20). Smoking prevalence in Turkey is $33.4 \%$ in the population above 18 years of age $(50.6 \%$ in males and $16.6 \%$ in females) and Turkey ranks in third place in terms of tobacco consumption in Europe (21). In our study, 53\% ( $81.5 \%$ of males, $31.9 \%$ of females) had a smoking history and current smoking rate was 34\% $(51.5 \%$ in males, $21 \%$ in females), which was consistent with the published data from Turkey. Interestingly, our female population reported even higher smoking rates than national average for Turkish females putting them at increased risk. According to a previous prevalence study from Turkey, smoking rate was $41.1 \%$ (males; $57.2 \%$, females; $25 \%$ ) which was slightly higher than our results, though male to female ratio was consistent with our data (15).

In Turkey, as Zonguldak is the major coal mining area, the most common blue-collar labor field for local inhabitants is coal mining. In our study, occupational exposure was present in $27.3 \%$ of the total population, more than half of which were coal miners. Smoking prevalence in coal miners was 88.8\% (79/91). All COPD patients with occupational exposure had other risk factors mainly smoking. A dramatic finding in our study was the fact that smoking prevalence in occupationally exposed group was significantly higher than in unexposed group [81.4\% $(136 / 167)$ vs $42.3 \%(188 / 444)(p<0.001)]$ rendering this subgroup even more risky. $64.3 \%$ (18/28) of COPD patients with occupational exposure were coal miners and smoking prevalence was $100 \%$ in this subgroup (coal miner COPD patients). COPD prevalence was $16.8 \%(28 / 167)$ among the occupationally exposed group and 19.8\% (18/91) among the coal miner group. Thus, these occupational characteristics and the significant high smoking rate among miners play a significant role in Zonguldak population putting them under a higher risk for developing COPD. 
COPD prevalence was higher in males than females. From an epidemiological point of view, males are classically more at risk for developing COPD compared to females because of their smoking habits. Although higher COPD prevalence rates have been reported in males compared to females, prevalence in females is rapidly increasing (22). In a recent report, smoking prevalence in females has been reported a $16.6 \%$ in Turkey but it is even higher in our series (21). Progressively, however, and depending on the country, females who smoke as much as males seem to have an equivalent risk of developing COPD (18). Whether females are more at risk for developing COPD than males with similiar smoking habits is still under debate $(23,24)$. In our study low smoking prevalence $(p<$ $0.001)$ and low occupational exposure $(p<0.001)$ in females compared to males can explain lower prevalence of COPD in females. In the other hand we must consider that in a recent study COPD prevalance among nonsmokers was found $6.9 \%$ (25). In the published literature, biomass smoke exposure has also been reported a significant risk factor for rural Turkish women (13). Remarkably, we found that high biomass smoke exposure rate contributed to COPD development in females as well as males in our study. This finding can be explained either because we studied an urban population rather than a rural population or because of the potential equal rates of exposure of both genders to biomass smoke, coming from burning coal or wood either for heating or cooking purposes both indoors and outdoors due to unavailable clean natural gas supplies to the city of Zonguldak.

Passive smoking is also an important risk factor for females which was reported in $26.5 \%$ of female study population. Studies showed that passive smoking was related to COPD development (26). In our study, almost half of the nonsmokers reported passive smoking. Passive smoking prevalence is significantly higher in females compared to males in our study and seemingly a significant risk factor for developing COPD in females. These numbers may be expected to decrease in Turkey as law makers passed more strict smoking bans in recent years after this study period aiming to decrease passive exposure to smoking in public.

Outdoor air pollution contributes to pulmonary function impairment and the development of COPD (17). Künzli et al. reported that prevalence of COPD increased in parallel with average particulate matter $\left(\mathrm{PM}_{10}\right)$ concentration in a unit air (27). According to data released by State Statistics Institute of Turkey, Zonguldak was among the most polluted cities of Turkey, with one of the highest average $\mathrm{PM}_{10}$ concentration (28). Annual $\mathrm{PM}_{10}$ concentrations of the period from 2007 to 2009 in Zonguldak province were reportedly $125 \mathrm{mcg} / \mathrm{m}^{3}, 101 \mathrm{mcg} / \mathrm{m}^{3}$ and 82 $\mathrm{mcg} / \mathrm{m}^{3}$ respectively. We can thus suggest that high levels of $\mathrm{PM}_{10}$ concentrations in Zonguldak may have contributed to higher COPD prevalence.

Normal lung development is characterized by growth of pulmonary function during childhood and adolescence until peak lung function, as measured by $\mathrm{FEV}_{1}$, is reached by age $18-20$ years. Pulmonary function then plateaus and further declines as a feature of normal aging (29). A two-fold increase in the prevalence of COPD was observed for every 10-year increment in age (14). On the other hand, declining pulmonary function as a feature of normal aging can also cause overestimation of COPD prevalence in elderly patients. We also observed a higher mean age in the COPD patients compared to the mean age in subjects without COPD. COPD prevalence was also increasing significantly with age categories $(p=0.036)$, OR reaching to 1.51 for the subjects above 70 years of age (Table 3 ). This finding was in accordance with the published literature. Turkey has a younger population compared to the industrialized nations. Thus we may also speculate that we can expect a further increase in the COPD prevalence as Turkish population ages with this very high smoking rate especially in males.

We could not evaluate the COPD patients according to combined COPD assessment because of the lack of some data such as Modified Medical Research Council Dyspnea Scale, COPD assessment test and the number of hospitalizations due to acute exacerbation of COPD in the past one year (30).

In conclusion, COPD is prevalent and an important public health problem in central Zonguldak province, and high prevalence of active and passive smoking, high levels of biomass smoke exposure and high prevalence of coal mining as a potential occupational risk in this population have important public health consequences with regard to COPD. Thus more effective national policies must be enacted to increase the awareness of COPD and to reduce the risk factors like smoking (both active and passive), biomass smoke exposure, occupational exposure and air pollution. We believe that our results will contribute to the future studies investigating COPD prevalence and risk factors in Turkey and around the world.

\section{CONFLICT of INTEREST}

None declared. 


\section{REFERENCES}

1. Rabe KF, Hurd S, Anzueto A, Barnes PJ, Buist SA, Calverley $P$, et al. Global strategy for the diagnosis, management, and prevention of chronic obstructive pulmonary disease: GOLD executive summary. Am J Respir Crit Care Med 2007; 176:532-55.

2. Mannino DM. COPD: epidemiology, prevalence, morbidity and mortality, and disease heterogeneity. Chest 2002;121(Supp/ 5):S121-S126.

3. Viegi G, Pistelli F, Sherrill DL, Maio S, Baldacci S, Carrozzi L. Definition, epidemiology and natural history of COPD. Eur Respir J 2007;30:993-1013.

4. Lopez AD, Shibuya K, Rao C, Mathers CD, Hansell AL, Held $L S$, et al. Chronic obstructive pulmonary disease: current burden and future projections. Eur Respir J 2006;27:397412.

5. Menezes AM, Perez-Padilla R, Jardim JR, Muiño A, Lopez $M V$, Valdivia $G$, et al. Chronic obstructive pulmonary disease in five Latin American cities (the PLATINO study): a prevalence study. Lancet 2005;366:1875-81.

6. Jemal A, Ward E, Hao Y, Thun M. Trends in the leading cause of death in the United States. JAMA 2005;294:1255-9.

7. Muray Cl, Lopez AD. Alternative projections of mortality and disability by cause 1990-2020: Global Burden of Disease Study. Lancet 1997;349:1498-504.

8. Halbert RJ, Isonaka S, George D, Igbal A. Interpreting COPD prevalence estimates: what is the true burden of disease? Chest 2003;123:1684-92.

9. Halbert RJ, Natoli IL, Gano A, Badamgarav E, Buist AS, Mannino DM. Global burden of COPD: systematic review and meta-analysis. Eur Respir J 2006;28:523-32.

10. Lindberg A, Jonsson AC, Rönmark $E$, Lundgren $R$, Larsson $L G$, Lundbäck B. Prevalence of chronic obstructive pulmonary disease according to BTS, ERS, GOLD and ATS criteria in relation to doctor's diagnosis, symptoms, age, gender, and smoking habits. Respiration 2005;72:471-9.

11. Mannino DM, Homa DM, Akinbami LI, Ford ES, Redd SC. Chronic obstructive pulmonary disease surveillance-United States, 1971-2000. MMWR Surveill Summ 2002;51:1-16.

12. Zhong N, Wang C, Yao W, Chen P, Kang J, Huang S, et al. Prevalence of chronic obstructive pulmonary disease in China: a large, population-based survey. Am I Respir Crit Care Med 2007;176:753-60.

13. Kiraz K, Kart L, Demir R, Oymak S, Gulmez I, Unalacak M, et al. Chronic pulmonary disease in rural women exposed to biomass fumes. Clin Invest Med 2003;26:243-8.

14. Buist AS, McBurnie MA, Vollmer WM, Gillespie S, Burney P, Mannino DM, et al. International variation in the prevalence of COPD (the BOLD Study): a population-based prevalence study. Lancet 2007;370:741-50.

15. Gunen H, Hacievliyagil SS, Yetkin O, Gulbas G, Mutlu LC, Pehlivan E. Prevalence of COPD: first epidemiological study of a large region in Turkey. Eur I Intern Med 2008; 19:499-504.
16. Deveci F, Deveci SE, Türkoğlu S, Turgut T, Kirkil G, Rahman $S$, et al. The prevalence of chronic obstructive pulmonary disease in Elazig, Eastern Turkey. Eur I Intern Med 2011;22:172-6.

17. Eisner MD, Anthonisen N, Coultas D, Kuenzli N, PerezPadilla R, Postam D, et al. An official American Thoracic Society public policy statement: Novel risk factors and the global burden of chronic obstructive pulmonary disease. Am J Respir Crit Care Med 2010;182:693-718.

18. Raherison C, Girodet PO. Epidemiology of COPD. Eur Respir Rev 2009;18:213-21.

19. Postma DS, Bush A, van den Berge M. Risk factors and early origins of chronic obstructive pulmonary disease. Lancet 2015;385:899-909.

20. Tashkin DP, Murray RP. Smoking cessation in chronic obstructive pulmonary disease. Respir Med 2009;103:96374.

21. Bilir N. Dünyada ve Türkiye'de tütün kullanımı epidemiyolojisi. In: Aytemur ZA, Akçay Ş, Elbek $O$ (eds). Tütün ve Tütün Kontrolü. Istanbul: Toraks Kitapları, 2007:21-35.

22. Soriano IB, Maier WC, Egger P, Visick G, Thakrar B, Sykes I, et al. Recent trends in physician diagnosed COPD in women and men in the UK. Thorax 2000;55:789-94.

23. Mannino DM, Buist AS. Global burden of COPD: risk factors, prevalence, and future trends. Lancet 2007; 370:765-73.

24. Prescott E, Bjerg AM, Andersen PK, Lange P, Vestbo J. Gender difference in smoking effects on lung function and risk of hospitalization for COPD: results from a Danish Longitudinal population study. Eur Respir J 1997;10:822-7.

25. Nguyen Viet N, Yunus F, Nguyen Thi Phuong A, Dao Bich $V$, Damayanti T, Wiyono $W H$, et al. The prevalence and patient characteristics of chronic obstructive pulmonary disease in non-smokers in Vietnam and Indonesia: An observational survey. Respirology 2015;20:602-11.

26. Yin P, Jiang CQ, Cheng KK, Lam TH, Lam KH, Miller MR, et al. Passive smoking exposure and risk of COPD among adults in China: the Guangzhou Biobank Cohort Study. Lancet 2007;370:751-7.

27. Künzli $N$, Kaiser $R$, Rapp $R$, Sommer $H$, Wanner $H U$, Seethaler $R$, et al. Air pollution in Switzerland--quantification of health effects using epidemiologic data. Schweiz Med Wochenschr 1997;127:1361-70.

28. Republic of Turkey Turkish Statistical Institute. Erişim tarihi: 14 Nisan 2015. Available from: http://www.turkstat.gov.tr/ PreHaberBultenleri.do?id=8663.

29. Speizer FE, Tager IB. Epidemiology of chronic mucus hypersecretion and obstructive airways disease. Epidemiol Rev 1979;1:124-42.

30. The Global Initiative for Chronic Obstructive Lung Disease (GOLD). Erişim tarihi: 14 Nisan 2015. Available from: http://www.goldcopd.org/uploads/users/files/GOLD_ Report_2015_Apr2. Pdf. 